\title{
Synthesis and Crystal Structure of a Three-Dimensional Nickel(II) Coordination Polymer with 1,4-Bis(3-pyridyl)-2,3-diazo-1,3-butadiene as a Ligand
}

\author{
Gene-Hsiang LEE and Hsin-Ta WANG ${ }^{\dagger}$ \\ Institute of Organic and Polymeric Materials, National Taipei University of Technology, Taipei 106, Taiwan
}

\begin{abstract}
A new 3D metal-organic coordination polymer, $\left[\mathrm{Ni}_{2}(\mathrm{~L})_{3}\left(\mathrm{NO}_{3}\right)_{4} \cdot \mathrm{EtOH}\right]_{n}(\mathrm{~L}=1$,4-bis(3-pyridyl)-2,3-diazo-1,3-butadiene), was synthesized under the solvothermal condition. It is noteworthy that all of the bridging ligands with a bismonodentate mode connect the $\mathrm{Ni}$ (II) ions to form a 3D metal-organic polymeric framework that allows a $1 \mathrm{D}$ microporous channel with dimensions of ca. $6.7 \times 8.5 \AA^{2}$ along the $a$-axis. The EtOH guest molecules are intercalated into these channels.
\end{abstract}

(Received August 3, 2006; Accepted November 2, 2006; Published on web January 18, 2007)

In recent years, coordination polymers ${ }^{1-5}$ have been synthesized extensively because of their fascinating structural diversity and potential applications as functional materials. To date, a number of one-, two- and three-dimensional infinite frameworks have been associated with linear $N, N^{\prime}$-bidentate spacers. Much of the work has been focused on rigid ligands, such as $4,4^{\prime}$ bipyridine, and pyrazine and its analogues. A rigid ligand, 1,4bis(3-pyridyl)-2,3-diazo-1,3-butadiene (L), has two pyridyl groups connected by a zigzag $-\mathrm{CH}=\mathrm{N}-\mathrm{N}=\mathrm{CH}-$ bridge, which coordinates the transition metal ions. The structure of $\left[\mathrm{Co}(\mathrm{SCN})_{2}(\mathrm{~L})_{2} \cdot 2 \mathrm{CH}_{2} \mathrm{Cl}_{2}\right]_{n}$ (ref. 2) features a two-dimensional (2D) non-interpenetrating metal-organic framework with a distorted square pattern as the basic structure. Other isomorphous metal-organic framework structures of $\left[\mathrm{Co}\left(\mathrm{NO}_{3}\right)_{2}(\mathrm{~L})_{1.5} \cdot \mathrm{CH}_{2} \mathrm{Cl}_{2}\right]_{n}$ and $\left[\mathrm{Cd}\left(\mathrm{NO}_{3}\right)_{2}(\mathrm{~L})_{1.5} \cdot \mathrm{CH}_{2} \mathrm{Cl}_{2}\right]_{n}$, which adopt a "polycyclohexane" structural motif, have also been

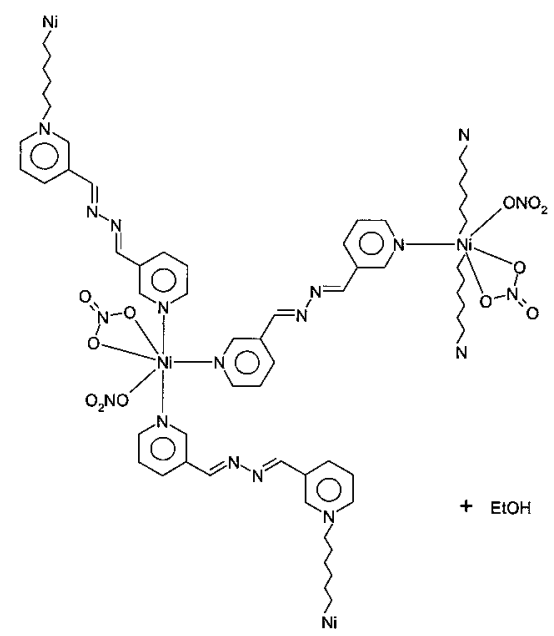

Fig. 1 Chemical structure.

$\doteqdot$ To whom correspondence should be addressed.

E-mail: htwang@ntut.edu.tw reported. ${ }^{3}$ In this paper, we report the synthesis and crystal structure of a coordination polymer, $\left[\mathrm{Ni}_{2}(\mathrm{~L})_{3}\left(\mathrm{NO}_{3}\right)_{4} \cdot \mathrm{EtOH}\right]_{n}$.

Solvents and metal salts (analytical grade) for syntheses were used without further purification. The ligand was prepared by a literature method. ${ }^{3}$ The title compound was prepared from a mixture of $\mathrm{Ni}\left(\mathrm{NO}_{3}\right)_{2} \cdot 6 \mathrm{H}_{2} \mathrm{O}(29.1 \mathrm{mg}, 0.1 \mathrm{mmol})$ and $\mathrm{L}$ ligand $(31.5 \mathrm{mg}, 0.15 \mathrm{mmol})$ in ethanol $(5 \mathrm{ml})$ by heating at $150^{\circ} \mathrm{C}$ for

Table 1 Crystal and experimental data

Formula: $\mathrm{C}_{38} \mathrm{H}_{36} \mathrm{~N}_{16} \mathrm{O}_{13} \mathrm{Ni}_{2}$

Formula weight $=1042.25$

Crystal system: monoclinic

Space group: $P 2_{1} / c$

$Z=4$

$a=16.318(1) \AA$

$b=14.9976(8) \AA$

$c=19.692(1) \AA$

$\beta=98.360(2)^{\circ}$

$V=4768.0(5) \AA^{3}$

$D_{\mathrm{x}}=1.452 \mathrm{~g} / \mathrm{cm}^{3}$

$\mu\left(\right.$ Mo $\left.K_{\alpha}\right)=0.867 \mathrm{~mm}^{-1}$

$F\left(\begin{array}{lll}0 & 0 & 0\end{array}\right)=2144$

Crystal size $(\mathrm{mm}): 0.25 \times 0.25 \times 0.05$

$T=(150 \pm 1) \mathrm{K}$

$2 \theta_{\max }=50.0^{\circ}$ with Mo $K_{\alpha}$

No. of reflection used: 8404

Goodness-of-fit $=1.065$

$R, w R 2=0.073,0.185$

$(\Delta / \sigma)_{\max }=0.001$

$(\Delta \rho)_{\max }=1.167 \mathrm{e}^{-3}$

$(\Delta \rho)_{\min }=-0.371 \mathrm{e}^{-3}$

Measurement: Bruker SMART APEX CCD

Program system: SMART V5.625 and SAINT V6.22

Structure determination: SHELXS-97

Refinement: full matrix: SHELXL-97

CCDC 608268 contains the supplementary crystallographic data for this paper. These data can be obtained free of charge from the Cambridge Crystallographic Data Centre via www.ccdc.cam.ac.uk/data_request/cif. 
Table 2 Selected bond lengths $(\AA)$ and bond angles ( $\left.{ }^{\circ}\right)$

\begin{tabular}{lrlr}
\hline $\mathrm{Ni}(1)-\mathrm{O}(1)$ & $2.142(4)$ & $\mathrm{Ni}(2)-\mathrm{O}(7)$ & $2.095(4)$ \\
$\mathrm{Ni}(1)-\mathrm{O}(2)$ & $2.089(4)$ & $\mathrm{Ni}(2)-\mathrm{O}(8)$ & $2.146(4)$ \\
$\mathrm{Ni}(1)-\mathrm{O}(4)$ & $2.037(3)$ & $\mathrm{Ni}(2)-\mathrm{O}(10)$ & $2.044(4)$ \\
$\mathrm{Ni}(1)-\mathrm{N}(1)$ & $2.056(4)$ & $\mathrm{Ni}(2)-\mathrm{N}(4)$ & $2.047(5)$ \\
$\mathrm{Ni}(1)-\mathrm{N}(5)$ & $2.100(4)$ & $\mathrm{Ni}(2)-\mathrm{N}(7)$ & $2.140(5)$ \\
$\mathrm{Ni}(1)-\mathrm{N}(9)$ & $2.108(4)$ & $\mathrm{Ni}(2)-\mathrm{N}(12)$ & $2.107(4)$ \\
& & & \\
$\mathrm{O}(4)-\mathrm{Ni}(1)-\mathrm{N}(1)$ & $93.54(16)$ & $\mathrm{O}(10)-\mathrm{Ni}(2)-\mathrm{N}(4)$ & $94.74(16)$ \\
$\mathrm{O}(4)-\mathrm{Ni}(1)-\mathrm{O}(2)$ & $172.56(14)$ & $\mathrm{O}(10)-\mathrm{Ni}(2)-\mathrm{O}(7)$ & $170.11(15)$ \\
$\mathrm{N}(1)-\mathrm{Ni}(1)-\mathrm{O}(2)$ & $93.89(16)$ & $\mathrm{N}(4)-\mathrm{Ni}(2)-\mathrm{O}(7)$ & $95.11(16)$ \\
$\mathrm{O}(4)-\mathrm{Ni}(1)-\mathrm{N}(5)$ & $91.03(16)$ & $\mathrm{O}(10)-\mathrm{Ni}(2)-\mathrm{N}(12)$ & $88.41(16)$ \\
$\mathrm{N}(1)-\mathrm{Ni}(1)-\mathrm{N}(5)$ & $93.37(17)$ & $\mathrm{N}(4)-\mathrm{Ni}(2)-\mathrm{N}(12)$ & $94.50(17)$ \\
$\mathrm{O}(2)-\mathrm{Ni}(1)-\mathrm{N}(5)$ & $88.13(16)$ & $\mathrm{O}(7)-\mathrm{Ni}(2)-\mathrm{N}(12)$ & $90.00(16)$ \\
$\mathrm{O}(4)-\mathrm{Ni}(1)-\mathrm{N}(9)$ & $89.88(16)$ & $\mathrm{O}(10)-\mathrm{Ni}(2)-\mathrm{N}(7)$ & $91.77(17)$ \\
$\mathrm{N}(1)-\mathrm{Ni}(1)-\mathrm{N}(9)$ & $91.50(17)$ & $\mathrm{N}(4)-\mathrm{Ni}(2)-\mathrm{N}(7)$ & $88.51(19)$ \\
$\mathrm{O}(2)-\mathrm{Ni}(1)-\mathrm{N}(9)$ & $90.32(16)$ & $\mathrm{O}(7)-\mathrm{Ni}(2)-\mathrm{N}(7)$ & $89.30(16)$ \\
$\mathrm{N}(5)-\mathrm{Ni}(1)-\mathrm{N}(9)$ & $174.98(18)$ & $\mathrm{N}(12)-\mathrm{Ni}(2)-\mathrm{N}(7)$ & $176.97(18)$ \\
$\mathrm{O}(4)-\mathrm{Ni}(1)-\mathrm{O}(1)$ & $111.21(14)$ & $\mathrm{O}(10)-\mathrm{Ni}(2)-\mathrm{O}(8)$ & $109.33(14)$ \\
$\mathrm{N}(1)-\mathrm{Ni}(1)-\mathrm{O}(1)$ & $155.25(15)$ & $\mathrm{N}(4)-\mathrm{Ni}(2)-\mathrm{O}(8)$ & $155.80(15)$ \\
$\mathrm{O}(2)-\mathrm{Ni}(1)-\mathrm{O}(1)$ & $61.37(14)$ & $\mathrm{O}(7)-\mathrm{Ni}(2)-\mathrm{O}(8)$ & $60.88(14)$ \\
$\mathrm{N}(5)-\mathrm{Ni}(1)-\mathrm{O}(1)$ & $87.08(16)$ & $\mathrm{N}(12)-\mathrm{Ni}(2)-\mathrm{O}(8)$ & $88.87(16)$ \\
$\mathrm{N}(9)-\mathrm{Ni}(1)-\mathrm{O}(1)$ & $87.98(16)$ & $\mathrm{N}(7)-\mathrm{Ni}(2)-\mathrm{O}(8)$ & $88.21(17)$ \\
\hline
\end{tabular}

$48 \mathrm{~h}$ in a $23 \mathrm{ml}$ Teflon-lined stainless-steel autoclave container. The light-blue crystals were collected in $35 \%$ yield after the mixture was cooled to room temperature by a speed of $5^{\circ} \mathrm{C} / \mathrm{h}$.

A suitable single crystal was mounted on a glass fiber. Data collection was carried out on a BRUKER SMART APEX CCD diffractometer (Mo- $K_{\alpha}, \lambda=0.71073 \AA$ ) with the crystal cooled to $150(1) \mathrm{K}$ in a stream of $\mathrm{N}_{2}$ from Oxford Cryostream cooler. The program SAINT was used for cell refinement and data reduction. The SADABS program was applied for an absorption correction. The structure was solved by a direct method with SHELXS-97 and refined on $F^{2}$ with SHELXL-97. All non-hydrogen atoms were refined anisotropically. Hydrogen atoms were constrained to the ideal geometry using an appropriate riding model. Molecular graphics were plotted using SHELXTL. Crystal and experimental data are given in Table 1. The selected bond distances and angles are listed Table 2.

The chemical structure is shown in Fig. 1 and a discrete fragment of the molecular structure is shown in Fig. 2a. In contrast to those of $\left[\mathrm{Co}\left(\mathrm{NO}_{3}\right)_{2}(\mathrm{~L})_{1.5} \cdot \mathrm{CH}_{2} \mathrm{Cl}_{2}\right]_{n}$ and $\left[\mathrm{Cd}\left(\mathrm{NO}_{3}\right)_{2}(\mathrm{~L})_{1.5} \cdot \mathrm{CH}_{2} \mathrm{Cl}_{2}\right]_{n}$, where the metal ion has a heptacoordination, the structure of our complex shows that each $\mathrm{Ni}(\mathrm{II})$ ion has a hexa-coordination and lies in a distorted octahedral environment bonded with three bis-monodentate bridging ligands and two nitrate anions. One of the bridging ligands and two nitrates are positioned at the equatorial position, and the other two ligands are at the axial position. The nitrates bonded to the $\mathrm{Ni}$ ions adopt two binding modes: one is bidentated and the another is monodentated. The two pyridyls in the individual ligand are coplanar. As shown in Fig. 2a, the dihedral angles between the equatorial pyridyl and the axial pyridyls, which are coordinated to $\mathrm{Ni}(1)$, are $82.85^{\circ}$ and $86.00^{\circ}$, respectively. For the $\mathrm{Ni}(2)$ unit, both of the dihedral angles between the equatorial pyridyl and the axial pyridyls are $84.17^{\circ}$ and $84.84^{\circ}$, respectively. The Ni-N and Ni-O bond distances range from $2.047(5)-2.140(5) \AA$ and $2.037(3)-2.146(4) \AA$, respectively, which are comparable to the corresponding bond lengths found in $\left[\mathrm{Ni}\left(\mathrm{C}_{12} \mathrm{H}_{10} \mathrm{~N}_{4}\right)_{2}\left(\mathrm{NO}_{3}\right)_{2}(\mathrm{THF})_{1.66}\left(\mathrm{H}_{2} \mathrm{O}\right)_{0.33}\right]_{n}$ (ref. 4) (where $\mathrm{C}_{12} \mathrm{H}_{10} \mathrm{~N}_{4}=$ 1,4-bis(4-pyridyl)-2,3-diazo-1,3butadiene) and $\left[\mathrm{Ni}\left(4,4^{\prime} \text {-bpy }\right)_{2}\left(\mathrm{NO}_{3}\right)_{2} \cdot 2 \text { pyrene }\right]_{n}$ (ref. 5) (where $4,4^{\prime}$-bpy $=4,4^{\prime}$-bipyridine).

It is noteworthy that all of the bridging ligands with a bismonodentate mode connect the $\mathrm{Ni}(\mathrm{II})$ ions to form a 3D metal-

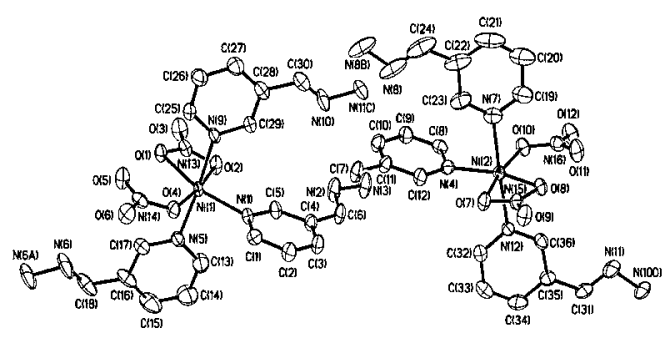

(a)

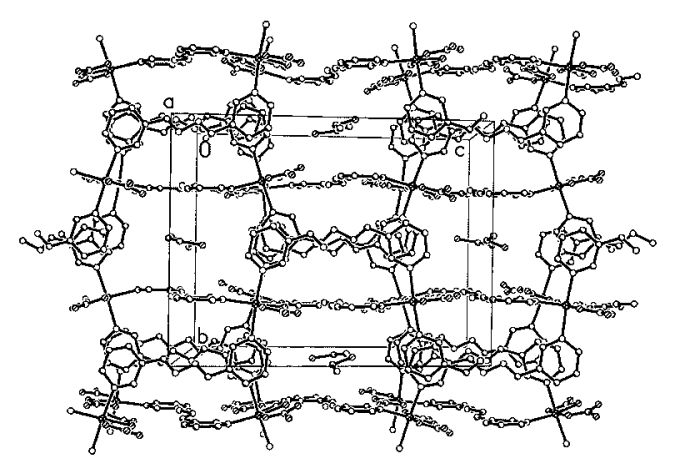

(b)

Fig. 2 (a) Discrete fragment of the molecular structure. Symmetry transformations used to generate equivalent atoms: $\mathrm{A},-x,-y,-z ; \mathrm{B}$, $-x+1,-y+1,-z+1 ; \mathrm{C},-x+1, y+1 / 2,-z+3 / 2 ; \mathrm{D},-x+1, y-1 / 2$, $-z+3 / 2$. (b) Packing diagram viewed along the $a$-axis. Hydrogen atoms were omitted for clarity.

organic polymeric framework that allows a 1D microporous channel with dimensions of $c a .6 .7 \times 8.5 \AA^{2}$ along the $a$-axis (Fig. 2b). The EtOH guest molecules are intercalated into these channels. The ethanol was found to be disordered over two positions $(\mathrm{O}(13), \mathrm{C}(37), \mathrm{C}(38)$ and $\mathrm{O}(14), \mathrm{C}(39), \mathrm{C}(40))$ and treated with $50 \%$ occupancies. No hydrogen bonding was found between the guest and the host molecules. The microporous channel dimensions are crystallographic scalar quantities, and do not account for the van der Waals radii of the atoms defining the microporous.

\section{Acknowledgements}

The authors thank the National Science Council of the Republic of China for financial supports.

\section{References}

1. S. A. Barnett and N. R. Champness, Coord. Chem. Rev., 2003, 246, 145.

2. Yu-Bin Dong, M. D. Smith, and H.-C. zur Loye, J. Solid State Chem., 2000, 155, 143.

3. Yu-Bin Dong, M. D. Smith, R. C. Layland, and H.-C. zur Loye, Chem. Mater., 2000, 12, 1156.

4. D. M. Ciurtin, Yu-Bin Dong, M. D. Smith, T, Barclay, and H.-C. zur Loye, Inorg. Chem., 2001, 40, 2825.

5. K. Biradha, K. V. Domasevitch, B. Moulton, C. Seward, and M. J. Zaworotko, Chem. Commun., 1999, 1327. 